\title{
Expressions of Empire and Four Kingdoms Patterns in the Aramaic Dead Sea Scrolls
}

\author{
Andrew B. Perrin
}

1 The Ongoing History of the Four Kingdoms*

As archaeologists sift through layers of forgotten ancient sites they often aim to detect social, political, and cultural shifts reflected in the rubble and remains of the material finds buried beneath. Discernable changes in the stratum of a site at times tell tales of dramatic upheavals, displacement, destruction, or reoccupation. In many instances, these layers attest to clashes of peoples existing under and against the long chain of empires that ruled from the Mediterranean basin to modern day India. One after another, powers ascended, expanded, and inevitably toppled to the emerging empire on deck. Empires, however, not only impacted physical landscapes and cultural heritage but also left impressions on the literary imaginations of ancient scribes and communities.

One prominent way writers reflected on their relation to the imperial powers of the past, present, and future was by fitting world history into four kingdoms schemes. Ancient texts featuring this motif reveal a conceptual and chronological stratigraphy, idealized and ideologically charged historiographies, and the diverse responses, reactions, and reflections of cultures clashing with overturning empires. In short, akin to the tells excavated by archaeologists, four kingdoms chronologies in ancient literature reflect memories of social, political, and cultural transitions through tiers of time.

When put in the panoramic perspective of writings across cultures and corpora, it is clear that speculation on the waxing-and-waning of empires in periodized chronologies was a far-reaching historiographical enterprise. As already established in the history of research, before Daniel beheld a four-tiered statue or watched in shock as four mythic beasts emerged from the sea, there are clear antecedents for this style of historiography in both Hellenistic and

* This research was made possible by funding and support from the Canada Research Chair in Religious Identities of Ancient Judaism at Trinity Western University and the Alexander von Humboldt Stiftung. The latter provided the opportunity to research and write at Ludwig-Maximilians-Universität München, where Professor Loren Stuckenbruck was an exceptional host and incisive dialogue partner for my ongoing work. Thanks also to Brian Felushko and Matthew Hama for their editorial work on this essay. 
ancient Near Eastern sources. ${ }^{1}$ In her excursus on the topic, Newsom underscored that in many ancient Jewish appropriations of the scheme the resulting historical reflection and expectation were both politicized and polemicized "into a model of resistance." As Portier-Young described, such expressions of resistance were concerned with interpreting "past and present, asserting the transience and finitude of temporal powers" while affirming "God's governance of time and the outworking of God's plan in history" and providing "hope for a transformed future."

The question of where and when this mechanism crossed the bridge into ancient Jewish thought, culture, and literature, however, is difficult to discern. Typically, the answer to this question is simple: Daniel. However, in view of a now fuller (albeit, fragmentary) collection of Aramaic writings from the midSecond Temple period recovered from the caves of the Judaean wilderness, it seems that the bridge was travelled by more than a single writing. This subsection of the Qumran discoveries included a suite of some thirty literary compositions penned in Aramaic. Incidentally, they share with Daniel a number of features that made the book an odd fit in the Hebrew Scriptures: these too are written in Aramaic, have a notable apocalyptic tone, and were also products of the mid-Second Temple period.

In what follows, I will (re)introduce aspects of the book of Daniel in the new setting of the Aramaic Dead Sea Scrolls as well as survey this collection for expressions of four kingdoms motifs or, in some cases, offer an alternative explanation to the historiographical approaches of select works. At the close of the paper, I will reflect on how setting the four kingdoms motif and Daniel in this broader context may shed light on how we understand the

1 Joseph Ward Swain, "The Theory of the Four Monarchies: Opposition History under the Roman Empire," CP 35 (1940): 1-21; Michael J. Gruenthaner, "The Four Empires of Daniel I: The Scriptural Evidence," свQ 8.1 (1946): 72-82; Michael J. Gruenthaner, "The Four Empires of Daniel II: The Evaluation of the Scriptural Evidence," "The Four Empires in the Fourth Sibyl and in the Book of Daniel," IOS 2 (1972): 148-75; Gerhard F. Hasel, "The Four World Empires of Daniel 2 against Its Near Eastern Environment," Jsот 4 (1979): 17-30; Walter Burkert, "Apokalyptik im frühen Griechentum: Impulse und Transformationen," in Apocalypticism in the Mediterranean World and the Near East, ed. David Hellholm (Tübingen: Mohr Siebeck, 1983), 235-54; Lucas Ernest, "The Origin of Daniel's Four Empires Scheme Re-Examined," TynBul 40 (1989): 185-202; John J. Collins, A Commentary on the Book of Daniel, Hermeneia (Minneapolis: Fortress, 1993), 166-70; Carol A. Newsom with Brennan W. Breed, Daniel: A Commentary, отL (Louisville: Westminster John Knox, 2014), $80-81$.

2 Newsom, Daniel, 81.

3 Anathea Portier-Young, Apocalypse Against Empire: Theologies of Resistance in Early Judaism (Grand Rapids: Eerdmans, 2011), 27. 
exchange and interactions of knowledge transmitted across cultures via Aramaic scribal tradition.

\section{Four Kingdoms Chronologies in the Early Composition, Transmission, and Reception of the Book of Daniel}

Research on Daniel has emphasized both the centrality and complexity of the book's chronologies. ${ }^{4}$ What I am most interested in here is how the book's eventual chronological complexity is a result of its redactional growth occasioned by, in many instances, the revision and extension of its political theology with reference to the four kingdoms motif.

Now decades old, Vermes's description of "rewritten bible" and Fishbane's discussion of "inner biblical exegesis" remain essential starting points for understanding the compositional growth, and even conversation between, traditions and tradents of the Hebrew Scriptures.

Perhaps fitting of their pioneering work, ongoing studies have revised, reworked, and reflected on their models for compositional growth adding both precision and nuance. Arguably, one of the more significant outcomes is the recognition that many of the strategies inherent to the growth of "biblical" literature are the very same approaches observed in scribal culture of ancient Judaism that continued to innovate, create, and compose literature on the basis of antecedent material. Most of the compositions included in such treatments, however, have a longer heritage in ancestral traditions and larger intervals of time between extension and formation of traditions. ${ }^{5}$

Our traditions that surface in Daniel, however, evidence historiographical revision very early on in their lifespan. An Aramaic/Hebrew hybrid form of the work came together by the mid-16os BCE. While more work needs to be done

4 For a recent study and past bibliography on the complex chronologies in Daniel, see Michael Segal, "Calculating the End: Inner-Danielic Chronological Developments," VT 68 (2018): $272-96$.

5 Michael Fishbane, Biblical Interpretation in Ancient Israel (Oxford: Clarendon Press, 1988); Géza Vermes, Scripture and Tradition in Judaism: Haggadic Studies, SPB 4 (Leiden: Brill, 1961; 2nd ed., 1973). For a recent reconsideration of the problems and prospects of Vermes's formulation, see József Zsengellér, ed., Rewritten Bible after Fifty Years: Texts, Terms, or Techniques, JSJS 166 (Leiden: Brill, 2014). In general, discussions of so-called "rewritten" or "parascriptural" texts have tended toward analyses of the generative process of largely Pentateuchal traditions in the mid-Second Temple period. For an application toward prophetic literature, see George Brooke, "Parabiblical Prophetic Narratives," in The Dead Sea Scrolls After Fifty Years: A Comprehensive Assessment, ed. James C. VanderKam and Peter W. Flint (Leiden: Brill, 1998), 1:271-301. 
on the text and codicology of the Qumran Daniel manuscripts, it strikes me that the revising activity of the early Aramaic/Hebrew Daniel materials must have occurred in short order given the proximity of our earliest witnesses discovered at Qumran to the compositional date. ${ }^{6}$

Close study of the evolving traditions within this hybrid book reveals redactional stages occasioned primarily by changing political situations. Kratz offered the most sophisticated argumentation in this regard. Some of the most visible incremental revision involved scribal activity centered on the historiographical structures for the exchange of empires. For example, Kratz demonstrated that the extension of the kingdoms chronology in the earlier Aramaic chapters involved a secondary addition of the statue's iron-clay toes (Dan 2:41-43) as well as the multiplication of horns (Dan 7:20-24). This redactional activity not only contributed to the form of an existing Aramaic tradition, it was generative for the ongoing growth of the Daniel tradition in the Hebrew chapters. In this way, there is a space for merging discussions of redaction with observations on the process of rewriting, both considered at the level of composition.

Collins noted that, while Daniel is not technically pseudepigraphic, as the tradition develops, Daniel becomes a pseudonym. I argue elsewhere that one of the first places we see this is within the biblical book, particularly in the latter Hebrew chapters. From this perspective, Daniel 8-12 is a parascriptural tradition developed out of, and in interaction with, the earlier Aramaic chapters. ${ }^{7}$ Furthermore, part of what occasioned this fresh first-person take on the tradition was the reception of an Aramaic Daniel tradition that was

6 As Cross noted in one of our earliest introductions to the Qumran discoveries, the latesecond century все palaeographical date of one of the Qumran Daniel texts, 4QDanielc, indicates that this remarkable fragmentary manuscript is "closer to the original edition of a biblical work than any biblical manuscript in existence" (Frank Moore Cross, The Ancient Library of Qumran, 3rd ed. [Minneapolis: Fortress Press, 1995], 43). Prior to the discovery of the scrolls, the compositional history of Daniel was known to include at least two main editions of the book: a shorter version represented primarily by the Hebrew/Aramaic witnesses of the Masoretic tradition and a longer version represented by two main Greek translations (the Old Greek and Theodotion) (see Arie van der Kooij, "Compositions and Editions in Early Judaism: The Case of Daniel," in The Text of the Hebrew Bible and Its Editions: Studies in Celebration of the Fifth Centennial of the Complutensian Polyglot, ed. Andrés Piquer Otero and Pablo A. Torijano Morales, THBSup 1 [Leiden: Brill, 2016], 428-48). As Ulrich (Eugene C. Ulrich, The Dead Sea Scrolls and the Origins of the Bible, SDSSRL [Grand Rapids: Eerdmans, 1999], 96-97) documented and described, the Qumran Daniel fragments generally cohere to the structure and scope of the shorter edition. However, they also contain previously unknown data indicating textual diversity even within this emerging edition.

7 On this, see Andrew B. Perrin, "Redrafting the Architecture of Daniel Traditions in the Hebrew Scriptures and Qumran," JTS (forthcoming, 2021). 
itself a product of a scribal culture that innovated traditions by updating their political outlook and structures in a rolling process of composition.

Where do we see this in the biblical book? Kratz observed that some of the redactional contributions to the Aramaic materials are linked to the development of later Hebrew materials, particularly Daniel 11. He wrote, "In chapter 11 the visions of the four kingdoms (chapters 2 and 7) and of the four Diadochi (chapter 8) are taken up and brought up-to-date. On the other hand, the additions in chapters 2, 7 and 8 anticipate these expansions in both matters of content and language." 8 While shifting the identification of the four kingdoms was not the nature of this updating — as is the case in later Second Temple period traditions such as those in 4 Ezra or Josephus-the scribe/redactor of Daniel 11 participated in a particularizing type historiography. There is, or course, a long list of exegetical and historical problems in the opening lines of Daniel 11, but the author of this material is clearly building on a four kingdoms schema. Yet he did not update the schema itself. Rather, he pursued a line of explanation and expectation focused now on happenings in recent or contemporary days under the fourth empire.

This brief account of the development of an early Daniel tradition in view of the four kingdoms motif allows for some preliminary remarks. First, the composition, transmission, and reception of the book are all related and part of a dynamic process. Second, the book's political ideologies and historiographical structures were some of the main areas that enabled this sort of scribal redaction. ${ }^{9}$ Third, while this type of compositional activity is something we might recognize within "biblical" literature, Daniel is an ideal case to show this phenomenon is formative to materials built and based within the mid-Second Temple period. Fourth, in the context of the Aramaic Dead Sea Scrolls, this sort of compositional activity may fit within a larger framework, as the writers of several other materials were adept at extending antecedent, ancestral traditions into new compositions by various means.

While more could be said on each of these points, in the interests of expanding our view of this Aramaic tradition, I will now turn my attention to one

8 Reinhard G. Kratz, "The Visions of Daniel," in The Book of Daniel: Composition and Reception, ed. John J. Collins and Peter W. Flint, VTSup 83, FIOTL 2 (Leiden: Brill, 2001), 1:91-113, here 104. For a fuller treatment of this topic, see also Reinhard G. Kratz, Translatio imperii: Untersuchungen zu den aramäischen Danielerzählungen und ihrem theologiegeschichtlichen Umfeld, wMANT 63 (Neukirchen-Vluyn: Neukirchener Verlag, 1987).

9 The trend of updating ex eventu political outlooks is a wider phenomenon, as demonstrated most recently by Matthew Neujahr, Predicting the Past in the Ancient Near East: Mantic Historiography in Ancient Mesopotamia, Judah, and the Mediterranean World, BJs 354 (Providence: Brown University Press, 2012). 
of the clearest contributors to four kingdoms chronologies, the aptly named text, 4QFour Kingdoms.

\section{The Aramaic 4QFour Kingdoms}

The work known as 4 QFour Kingdoms is represented by three fragmentary manuscripts from Qumran Cave Four (4QFour Kingdoms ${ }^{\mathrm{a}-\mathrm{c}}$ [4Q552, 4Q553, $\left.\left.4 \mathrm{Q}_{553} \mathrm{a}\right]\right) .{ }^{10}$ The earliest of these seems to be 4 Q553, which Puech dated palaeographically to ca. $100-5 \mathrm{O} \mathrm{BCE}$, though the compositional date of the work is certainly earlier than the material evidence. ${ }^{11}$ How much earlier depends on many factors. One key factor is the scope of the kingdoms behind the dreamvision symbols. The text purports to disclose special knowledge on the course of history through a revelatory account of either a Jewish courtier or pagan king using the symbolism of four trees that dialogue with an unknown (or unnamed) dreamer. ${ }^{12}$ Perhaps the most relevant excerpt of this composition for our topic, is found in 4 Q552 1 ii, which has some minor overlaps with 4 Q553 2 $\mathrm{ii}+3$ indicated in bold..$^{13}$

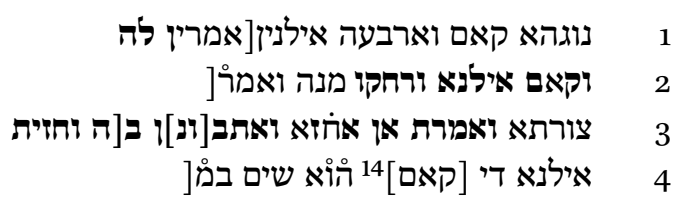

10 To avoid confusion in this discussion, I will use the term "four kingdoms" to signify the historiographical mechanism and the title "4QFour Kingdoms" to refer to the Aramaic work represented by the three Cave Four manuscripts noted above.

11 Émile Puech, Qumrân Grotte 4.XXVII: Textes araméens, deuxième partie: 4Q550-4Q575a, 4Q580-4Q587, DJD 37 (Oxford: Clarendon, 2009), 74.

12 The court setting of the work is confirmed by the phrase ואמר לי מלכא ("and the king said to me") in 4Q552 $1 \mathrm{i}+28$. While the interrogation and dialogue with the symbols within the episode is a unique feature of this dream-vision text, the seer also seems to have benefited from some encounter or explanation from an angelic being, as suggested by the phrase לי מלאכא ("to me the angel") in 4Q553a 2 ii 2.

13 The transcription is based on Puech (Qumrân Grotte 4.XXVII: Textes araméens, deuxième partie, 64), though I have not retained his more extensive reconstructions. Translation mine.

14 There is an effaced section of the manuscript here that is unlikely a vacat. The restored verb in the above transcription is at Puech's recommendation (Qumrân Grotte 4.XXVII: Textes araméens, deuxième partie, 66). The suggestion is not certain but makes sense in light of the context of the previous lines and fits the available space in the manuscript. Note also that the monarch may have referenced trees קאמין ("standing)" before him in 4 Q5521 1 + 29 . 


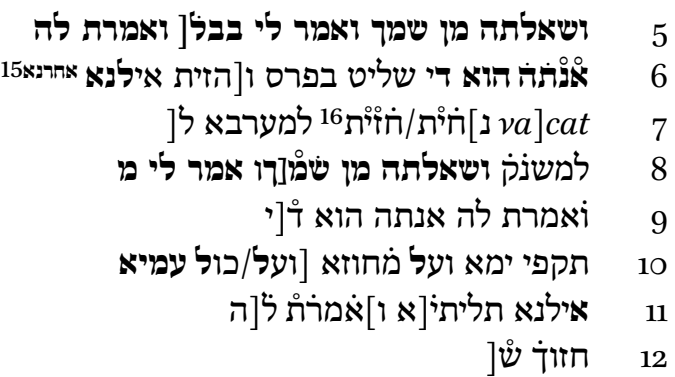

1 the dawn arose, and four trees[saying to him ...]

2 and the tree stood and they went far from him and it said[...]

3 the image. And I said, "Where may I look and under[stan]d it?" [And I saw]

4 the tree that [arose] was set in[...]

5 And I asked it, "What is your name?" And he said to me, "Babylon." [And I said to it, ]

6 "You are him who rules in Persia." And[I saw another tree]

7 [I loo]ked to the west to[...]

8 to torment. And I asked it, "What is [your] name?" [And it said to me ...]

9 And I said to it, "You are him wh[o ...]"

10 the vigor of the sea and over the harbor[and over the peoples]

11 [the] third tree. [And] I asked i[ $t$...]

12 your appearance $[\ldots]$

While the fragment is damaged, the surviving text allows for both a few observations and open questions regarding the work's historiographical structure and potential relation to other early Aramaic expressions of the four kingdoms motif.

The reference to the symbols of "four trees" (4Q552 1 ii 1) confirms we are indeed in the framework of some four kingdoms chronology. I have argued elsewhere that the most likely configuration of the kingdoms based on internal

15 Puech (Qumrân Grotte 4.XXVII: Textes araméens, deuxième partie, 66) suggested that this adjective, which is extant in the overlapping text of 4 Q553 $3+2$ ii +45 , may have been inserted supralinearly at the end of this line or perhaps included in the lacuna at the beginning of line 7. For a similar presentation, see Klaus Beyer, Die aramäischen Texte vom Toten Meer samt den Inschriften aus Palästina, dem Testament Levis aus der Kairoer Genisa, der Fastenrolle und den alten talmudischen Zitaten: Ergänzungsband (Göttingen: Vandenhoeck \& Ruprecht, 1994), 108.

16 My reading of this character cluster differs from that of Puech (Qumrân Grotte 4.XXVII: Textes araméens, deuxième partie, 64). 
TABLE 1 Proposed referents for the historical scheme of 4QFour Kingdoms ${ }^{\mathrm{a}}$

\begin{tabular}{|c|c|c|c|c|}
\hline & Kingdom \# 1 & Kingdom \#2 & Kingdom \# 3 & Kingdom \#4 \\
\hline Collins & Babylon-Persia & Greece & $\begin{array}{l}\text { (a) Ptolemaic Egypt } \\
\text { (b) Seleucid Syria }\end{array}$ & $\begin{array}{l}\text { (a) Seleucid Syria } \\
\text { (b) Rome }\end{array}$ \\
\hline Cook & Babylon-Persia & Greece & Rome & Kingdom of God \\
\hline Flint & Babylon-Persia & Greece & $\begin{array}{l}\text { (a) Syria } \\
\text { (b) Rome }\end{array}$ & $\begin{array}{l}\text { (a) Rome } \\
\text { (b) Kingdom of God }\end{array}$ \\
\hline Hogeterp & Babylon-Persia & Media & $\begin{array}{l}\text { "Yawan" (i.e., Greece) } \\
\text { representing either: } \\
\begin{array}{ll}\text { (a) Kings } & \text { (b) Kings } \\
\text { of south } & \text { of Assyria } \\
\text { and north and Egypt }\end{array}\end{array}$ & $\begin{array}{l}\text { "Kittim" } \\
\text { (i.e., Rome) }\end{array}$ \\
\hline Perrin & Babylon-Persia & Greece & Rome & Kingdom of God \\
\hline Puech & Babylon-Persia & Media & Greece & Kingdom of God \\
\hline Reynolds & $\begin{array}{l}\text { Babylon-Persia } \\
\text { (and Media?) }\end{array}$ & $\begin{array}{l}\text { Greece (or } \\
\text { Macedonia) }\end{array}$ & Ptolemaic Egypt & Seleucid Syria \\
\hline
\end{tabular}

a This table is adapted and updated from my earlier discussion, Perrin, The Dynamics of Dream-Vision Revelation, 214. Data in this table derive from the following: John J. Collins, "Apocalypticism and Literary Genre in the Dead Sea Scrolls," in The Dead Sea Scrolls after Fifty Years: A Comprehensive Assessment, ed. Peter W. Flint and James C. VanderKam with the assistance of Andrea E. Alvarez, (Leiden: Brill, 1998-1999), 2:403-30; Peter W. Flint, "The Daniel Tradition at Qumran," in The Book of Daniel: Composition and Reception, eds. John J. Collins and Peter W. Flint, VTSup 83, FiotL 2 (Leiden: Brill, 20o1), 2:329-67; Michael Wise, Martin Abegg Jr., and Edward Cook, The Dead Sea Scrolls: A New Translation (New York: Harper One, 2005), 556; Puech, Qumrân Grotte 4.XXVII: Textes araméens, deuxième partie, 57-58; Albert L. A. Hogeterp, "Daniel and the Qumran Daniel Cycle: Observations on 4QFour Kingdoms $^{\mathrm{a}-\mathrm{b}}$ (4Q552-553)," in Authoritative Scriptures in Ancient Judaism, ed. Mladen Popović, JSJS 141 (Leiden: Brill, 2010), 173-91; and Bennie H. Reynolds III, Between Symbolism and Realism: The Use of Symbolic and Non-Symbolic Language in Ancient Jewish Apocalypses 333-63 B.C.E., JAJSup 8 (Göttingen: Vandenhoeck \& Ruprecht, 2011), 191, 199-201. In cases where two options have been proposed for a given kingdom, I include these under the same column as "a" and "b."

clues and external comparisons is: Babylon-Persia, Greece, Rome, and the eschatological rule of God. ${ }^{17}$ However, to put this in the context of the larger scholarly discussion, the following table indicates the variety of views on offer.

17 See Andrew B. Perrin, The Dynamics of Dream-Vision Revelation in the Aramaic Dead Sea Scrolls, JAJSup 19 (Göttingen: Vandenhoeck \& Ruprecht, 2015), 215-17. In summary, this determination is made on the following points. Tree \#1: The first tree reveals its identity 
What is common to all of these, and is clear in the text itself, is that the first tree/kingdom is a conglomerate. The tree names itself as Babylon (line 1), yet the dreamer later understands this as the ruler of Persia (line 9). Regardless of one's position on the identification of the later kingdoms in the more fragmentary parts of the texts, this consolidation of the empires in the first position seems to have been to free up a slot later on in the chronology. This is already an intriguing historiographical approach: it suggests an authorial commitment to the framework provided by the common four kingdoms mechanism as well as the ability to innovate within the parameters it provided. As is evident from the scholarly explanations of which four kingdoms are in view, all agree that the empires behind the symbols of the Aramaic 4 QFour Kingdoms accounted for something beyond the framework familiar from the book of Daniel (i.e., Babylon, Media, Persia, Greece). This, of course, leads to our next interpretive issue.

The use of a four kingdoms scheme in an Aramaic dream-vision text from the mid-Second Temple period invites the question of its orientation to the book of Daniel. Unlike the fragments collected under the modern title of Pseudo-Daniel (4Q243-244; 4Q245) which name Daniel on several occasions, ${ }^{18}$ the available 4 QFour Kingdoms fragments make no reference to Daniel. The identity of our seer is technically unknown. However, even if he was named

as "Babylon" (4Q552 1 ii 1). Judging by the dreamer's response in 4 Q552 1 ii 6 , this first kingdom is understood as a hybrid, representing the generic imperial foe in the east, "Babylon-Persia". Tree $\#_{2}$ : There are two items that suggest the second kingdom was "Greece". In line 7 the dreamer seems to look to the "west" to view this empire. By lines 9-10, he notes this kingdom's seafaring dominance. Both of these points are commensurate with "Greece," and not easily reconciled with an identification of a landlocked, eastern kingdom, such as "Media." Tree \#3: If the identification of "Greece" is correct, then the logical succession for the third tree is "Rome." Such a progression is evident in other four kingdoms schemes (Ant. 10.276; Sib. Or. 4.101-102; Tg. Ps.-J. at Gen 15:12; and Exod. Rab. 35:5; compare also the five kingdom scheme of Mek. de-Rabbi Ishmael Beshallah II.13O-42). Additionally, there is no hint in the fragments of an interest or awareness of either Diadochian divisions or the struggle under Antiochus IV. Tree \#4: Comparative studies on other ancient political propaganda suggest that the final kingdom in the sequence is postured as the capstone of history. Note, for example, the addition of Rome as the fifth kingdom in classical historiographies (Tacitus [Historiae v.8-9], Dionysius of Halicarnassus [Ant. Rom. I.2.2-4], Appian [Praef. 9], and Claudian [De consulatu Stilichonis III.159-66]). In light of this trend, this Qumran dream-vision text seems to have anticipated the arrival of the eternal rule of God, thought to be on the ever-near but never arriving horizon, now slated after Roman rule. 
"Daniel," as some have suggested, ${ }^{19}$ this would confirm only that the text was part of the growing Danielic tradition in the mid-Second Temple period, not dependence on the "biblical" book. As both Stuckenbruck and Tigchelaar noted, in view of the fragmentary evidence available, the association of the Aramaic 4QFour Kingdoms with either the character or book of Daniel is speculative. ${ }^{20}$

In lack of explicit links, perhaps implicit features may suggest some interaction between 4 QFour Kingdoms and the book of Daniel. As Hogeterp demonstrated, there are many terminological and literary affinities between the traditions. In the end, he proposed that "it stands to reason to suppose that 4QFour Kingdoms provided a general elaboration on Danielic themes and Danielic tradition," though was careful to caution that "the attribution of the composition to Daniel" is not certain. ${ }^{21}$ This conclusion, however, goes beyond the available evidence, particularly concerning the lexical data. Many (even most) of the features and items Hogeterp presented are not unique to this pair of texts. ${ }^{22}$ Most often, they stem from a larger, shared literary and linguistic foundation that appears to have been established in Aramaic scribal culture

19 Puech, Qumrân Grotte 4.XXVII: Textes araméens, deuxième partie, 57; Klaus Beyer, Die aramäischen Texte vom Toten Meer samt den Inschriften aus Palästina, dem Testament Levis aus der Kairoer Genisa, der Fastenrolle und den alten talmudischen Zitaten: Band 2 (Göttingen: Vandenhoeck \& Ruprecht, 2004), 144.

$20 \quad$ Loren T. Stuckenbruck, "The Formation and the Re-Formation of Daniel in the Dead Sea Scrolls," in The Bible and the Dead Sea Scrolls, Volume 1: Scripture and the Scrolls, ed. James H. Charlesworth (Waco: Baylor University Press, 2006), 1:101-3o; Eibert Tigchelaar, "Aramaic Texts from Qumran and the Authoritativeness of Hebrew Scriptures: Preliminary Observations," in Authoritative Scriptures in Ancient Judaism, ed. Mladen Popović, JsJs 141 (Leiden: Brill, 2010), 155-71.

21 Hogeterp, "Daniel and the Qumran Daniel Cycle," 189.

22 Of the many terminological features Hogeterp ("Daniel and the Qumran Daniel Cycle," 179-83) tracked in 4QFour Kingdoms, Daniel, and the larger data set of the Qumran Aramaic texts, there are four lexical items for which he accounted similarities only between 4 QFour Kingdoms and Daniel. Upon reevaluation, these too find a broader representation across the Aramaic Dead Sea Scrolls. The Aramaic term ("dawn") found in 4Q552 1 ii 1 and Dan 6:20 also occurs in 4Q580 1 ii 15. The noun אלינא ("tree") used several times in 4QFour Kingdoms and Dan 4:7-8, 11, 17, 20 occurs at least fourteen times across multiple other works in the Qumran Aramaic texts (1Q20 13:10; 4Q201 1 ii 4, 5, 9; 4Q204 1 i 28; 1 v 7; 1 xii 26, 28; 4Q205 1 xii 2; 4Q206 1 xxvi 15; 4Q211 1 i 4, 5; 4Q531 2 + 3 5; 4Q558 78 2). The configuration שליט ב ("ruler over") at 4Q552 1 ii 6, which Hogeterp suggests finds a "close parallel" to phrasing in Dan 4:22, 29; 5:21, 29, is in fact replicated in 4Q542 1 i 2-3 and $4 Q_{55} 7+7$ a 1. The claimed paralleled uses of the noun שלטן ("dominion") in 4Q553 1 i 4 and Dan 3:33; 4:19, 31; 6:27; 7:6, 12, 14, 26-27 occur at least fifteen times across the Aramaic Dead Sea Scrolls (4Q196 2 6; 4Q209 28 2; 4Q243 11 ii 3; 4Q246 1 ii 9; 4Q530 2 ii + 6-12(?) 16 [perhaps "ruler"]; 4Q544 2 13; 4Q546 5 1; 4Q550 1 6, 7; 4 6; 7 + 7a 4; 4Q558 5oa-b 3; $4 \mathrm{Q} 569$ 3a-b 2; 4Q570 203 ; 11 Q10 94 ). In view of this reevaluation, there are no demonstrably unique terms between 4 QFour Kingdoms and Daniel. 
as evidenced by their broader representation in narratives of the Aramaic texts among the Dead Sea Scrolls.

So what is the value of the $4 \mathrm{QFour}$ Kingdoms text for a study on the origins, development, and reception of the four kingdoms motif? First, it is a reminder that ancient Jewish literature can be studied regardless of whether it is related to, in conversation with, or develops out of the few writings from this period eventually canonized in Judaism and Christianity. Second, it demonstrates the scribal innovation of a structure that was part of a broader cultural repertoire of historiographical mechanisms for articulating imperial histories in antiquity. Third, it reveals that there was more than a single articulation of the four kingdoms model available in the Qumran Aramaic corpus, by implication, in the Dead Sea Scrolls collection, and presumably, in broader Second Temple period thought. If the Aramaic 4 QFour Kingdoms is not built on Daniel or, at a minimum, the relationship is indeterminate, then it indeed points beyond it. ${ }^{23}$

23 Nadav Sharon has recently advocated an alternate interpretation of 4QFour Kingdoms, which he was gracious enough to share with me in prepublication form (Nadav Sharon, "Four Kingdoms' in the Dead Sea Scrolls? A Reconsideration," DSD 27 [2020]: forthcoming). Sharon argues that the text does not feature a sequential historiography of four kingdoms but a geographical distribution of nations who are understood as a single, overarching empire. Sharon argues there is nothing inherent to the Aramaic 4 QFour Kingdoms to suggest a chronological succession of empires and that this has been inferred largely on account of Daniel's four kingdoms patterns. He proposes that the directional map of Noah's division of the land in Genesis Apocryphon provides a more helpful framework for guiding interpretation. This is a refreshing take on the text and rightfully takes into account perspectives now possible in light of the wider Qumran Aramaic collection. There are, however, some challenges to a strictly cartographical approach that, when addressed, may suggest a middle road between these interpretive options.

Any read of the Aramaic 4 QFour Kingdoms-including my own-is limited by the fragmentary evidence. Yet it is evident that the scribe of this text took efforts to limit his timeline or map to four kingdoms (see above). Given this emphasis, it would be unusual if the scribe were not deploying or modifying the four kingdoms motif, which is a well-worn historiographical mechanism that transcends cultures and corpora in both classical and Near Eastern sources as well as fits within a larger framework of conceptions and calculations of time in the Aramaic Dead Sea Scrolls. Additionally, while the division of the land in Genesis Apocryphon is certainly cartographical, it too has a chronological outlook. That text not only lays out the map but has an ex eventu character insofar as it foresees the future interaction of the people groups emerging from Noah's progeny (1Q20 14:17-19). In this respect, the expression of the four kingdoms motif in Daniel 7 might also be a beneficial conversation partner as the dream-vision there seems to express the crescendo of empires building on one another rather than their decisive breaks and transitions.

In these respects, I see the implications of Sharon's interpretation less as overturning the consensus interpretation of 4 QFour Kingdoms as an expression of the four kingdoms motif than as a reminder to take into account the geographical nature of the text, which 
Other (Potential) Takes on the Four Kingdoms Motif in the Qumran Aramaic Texts

The fragmentary manuscripts of the book of Daniel and 4QFour Kingdoms are our clearest examples of the deployment and development of the four kingdoms mechanism in the Aramaic Dead Sea Scrolls. There are, however, at least three other writings that either contain hints of other potential applications or have been interpreted along such lines. These include fragments or passages in the Aramaic New Jerusalem, Tobit, and Pseudo-Daniel. ${ }^{24}$

The discovery of the Dead Sea Scrolls included fragmentary materials of seven copies of the Aramaic New Jerusalem text: $1 \mathrm{QNJ}\left(1_{32}\right)$, $2 \mathrm{QNJ}(2 \mathrm{Q} 24), 4 \mathrm{QNJ}^{\mathrm{a}}$ (4Q554) 4QNJ ${ }^{\mathrm{b}}$ (4Q554a), 4QNJc (4Q555), 5QNJ (5Q15), and ${ }_{11} \mathrm{QNJ}$ (11Q18). While the full shape and setting of the narrative is unknown, the extant materials include a visionary tour complete with a blueprint of the residential quarters, street plan, and design of the eschatological city. At least one key fragment also includes material hinting at some succession of empires perhaps in the context of an expected battle. As is evident from the text and translation below, 4Q554 13 is highly fragmentary, with references to both empires and people groups at the fringes of the fragment. The transcription and translation of this fragment is as follows: ${ }^{25}$

is part of establishing the imperial timeline and footprints. It would be a false dichotomy to reduce our reading of 4 QFour Kingdoms to a chronology vs. cartography approach. The two are not mutually exclusive. On the contrary, it is evident that the symbolism and outlook of 4 QFourKingdoms are concerned with both space and time. These are both functions of its likely apocalyptic character, form, and historiography.

24 The highly fragmentary text known as 4 QpapVision ${ }^{\mathrm{b}}$ also includes several scattered symbolic elements, tropes, nations, and individuals or ages from the Israelite past. These remnants suggest the text included some review or structure of history, likely in a revelatory context. Unfortunately, the text is terribly fragmentary allowing only glimpses of the larger, now lost, composition. For a preliminary analysis, see Perrin, The Dynamics of Dream-Vision Revelation, 76-77.

25 The Aramaic text above is based on Puech (Qumrân Grotte 4.XXVII: Textes araméens, deuxième partie, 136), though I do not include his more extensive proposed reconstructions or alignment with $4 \mathrm{Q} 55414$, which is possible, but not certain. The translation is my own. For another presentation, see Lorenzo DiTommaso, The Dead Sea New Jerusalem Text: Contents and Contexts, TSAJ 110 (Tübingen: Mohr Siebeck, 2005), 66-67. 


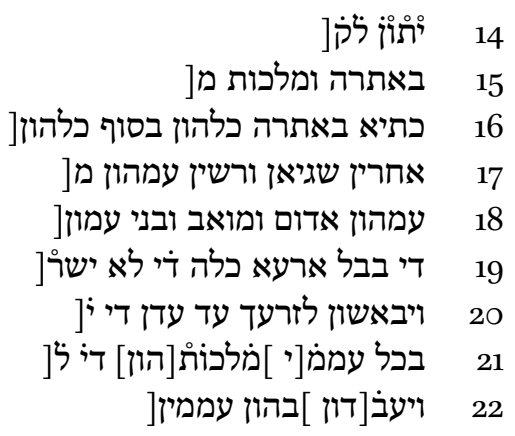

14 they will bring to ... [

15 in its place. And the kingdom of ... [

16 the Kittim in its place. All of them at the end of all of them[

17 others, numerous/great and powerful with them ... [

18 with them Edom, and Moab, and the Ammonites[

19 of Babylon, the land, all of it, which is not ... [

20 and they will be wicked toward your seed until the time of ... [

21 with all peoples [of their] kingdoms who ... [

22 and the nations will mak[e] in them

These scattered references to nations and peoples have been interpreted in various ways. The question for the interests of this essay, of course, is whether these hint at yet another take on the four kingdoms chronology. The fragment includes some phrasing suggesting the overturning of empires. The clearest instance of this is the phrase באתרה ("in its place/after it") in 4Q554 13 15-16, which likely implies the overturning and supplanting of political powers. ${ }^{26}$ These lines also reference כתיא ("the Kittim") and include the partial construct form ומלכות ("and the kingdom of"), which suggests the historiographical structure extended into the period of Hellenistic or Roman rule. In addition to naming some classical foes of Israel's past, line 19 references the more recent בבל ("Babylon").

In view of these glimpses into the theological and political vision of 4 Q554 13 , both Puech and DiTommaso perceived the remnants of geopolitical historiographical structures. Puech ventured an extensive reconstruction including: Assyria, Babylon, Media, Persia, the Kittim, Egypt or Greece, Edom, Moab, and the Ammonites. DiTommaso argued the partial remains of a four kingdoms

26 Compare the use of בתר to signal the transition between weeks in the Enochic Apocalypse of Weeks (4Q212 1 iv 15 [1 En. 91:12]). Though not extant in the Qumran Aramaic fragments, see also 1 En. 93:4, 5-9; 91:12, 14-15, 17. 
scheme, which he proposed originally included: Babylon, Persia, Media, and the Kittim. In different ways, these proposals also included the largely reconstructed reading "M[edia" (מי (מי) in line 15, which is possible, but survives only by the initial mem.

While both are correct in their shared acknowledgement of some historiographical mechanism in this fragment, unfortunately the extant terms and phrases confirm only that New Jerusalem's view of the eschatological future involved an expectation of overturning kingdoms. It is possible that this involved some schema or roster of ancient Near Eastern and Mediterranean empires; however, the scope and structure of this chronology are largely lost. If the reading "Media" is retained at line 15, and DiTommaso's proposal is entertained, the most intriguing aspect of this presentation is that the sequence of Babylon Persia at the outset is closer to the initial order of the 4 QFour Kingdoms than to the book of Daniel. In this, we may not have uncovered a certain four kingdoms schema but perhaps discovered a shared sequence of two early empires in previously unknown Aramaic texts.

Tobit

The book of Tobit is known in at least four Aramaic copies (4QTobit ${ }^{\mathrm{a}-\mathrm{d}}$ [4Q196199]) and the remains of a single Hebrew translation (4QTobit ${ }^{-}$[4Q20o]). ${ }^{27}$ The manuscript history of the book of Tobit is complex and diverse. In the large scope and most details, the Qumran manuscripts include a form of the text that resembles the lost Vorlage of the so-called "longer" Greek version. ${ }^{28}$ As such, when the Qumran Aramaic or Hebrew is not extant, this later Greek tradition can serve as a relative, though not certain, guide to the presumed Semitic language tradition of its Vorlage. This textual trajectory is relevant to the present example since the passage in question, Tob 14:3-4, is only partially

27 It is possible that $3 \mathrm{Q}_{14} 4$ also includes content from the book of Tobit, though this association has not been confirmed in view of the Cave Four materials (cf. 4Q196 14 ii 6-8; 4Q197 4 iii 2-5). See M. Baillet, J. T. Milik, and R. de Vaux, Les 'petites grottes' de Qumran, DJD 3, 2 vols. (Oxford: Clarendon, 1962), 103.

28 See Joseph A. Fitzmyer, "The Hebrew and Aramaic Fragments of Tobit from Qumran Cave 4," свQ (1995): 655-75. Even this characterization, however, is an oversimplification as the ancient medieval witnesses to Tobit resist simple categorizations. For a synopsis of all the available materials, see Stuart Weeks, Simon Gathercole, and Loren Stuckenbruck, The Book of Tobit: Texts from the Principal Ancient and Medieval Traditions, FoSub 3 (Berlin: Walter de Gruyter, 2004). 
extant in 4 Q198 1 and 4 Q200 7 ii, requiring us to look primarily to the later Greek text.

On his deathbed, the aging Tobit delivers a farewell discourse that blends wisdom and eschatological motifs. The longer Greek version presents Tob 14:3$4 \mathrm{~b}$ as follows:

Now when he was about to die, he called Tobias his son and commanded him, saying: "My child, take your children, and hurry off into Media, for I believe the word of God about Nineue, the things Naoum spoke, that all these things will come about and happen to Athour and Nineue. Also everything that the prophets of Israel spoke, those whom God sent, will happen. And not one of all their words will fail, but all will come true at their appointed times. So in Media there will be safety rather than among

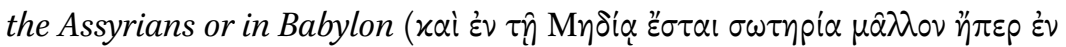

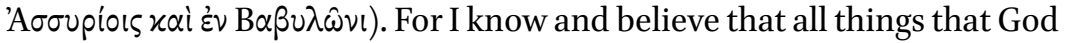
said will be fulfilled and will come to pass, and no utterance of his word shall fail."

Tob 14:3-4b NETS

Fitzmyer observed that this passage participates in a style of ex eventu prophecy. "Tobit is depicted as living at the peak of Neo-Assyria power in the 8th-7th century, but the author of the Tobit story, for whom the fall of Nineveh was a thing of the past, writes as an apocalyptic and casts history into the prophetic mold. This is why he makes Tobit speak of all things taking place at their appointed times." ${ }^{29}$ In this case, however, the prophetic voice focuses on the security of his progeny due to the imminent changing of the imperial guard that will impact their homeland and that of their neighbors to the south in the kingdom of Judea. This, of course, will involve an exchange of rule from Assyria to Babylon, but Media is not necessarily a component of a sequence in Tob 14:4. Rather, it is a place for temporary safe haven, which is the key element retained in the likely later, streamlined shorter version of the passage as found in Codex Vaticanus. ${ }^{30}$

In this way, while the book of Tobit engages in ex eventu prophecy that relates to political events and imperial oversight it does not do so by use of an overt four kingdoms chronology.

29 Joseph A. Fitzmyer, Tobit, CEJL (Berlin: Walter de Gruyter, 2003), 327.

30 Newsom (Daniel, 8o) did, however, understand the references to Assyria, Media, and Persia as sequential and drew a parallel with Sib. Or. 4.49-101. 


\section{$7 \quad$ Pseudo-Daniel}

The so-called Pseudo-Daniel materials from Qumran employed a diversity of historiographical strategies. In the work represented by 4Q243-244 we have the remains of what seems to be a broad historical review involving episodes, eras, and individuals from the ancestral past, through the exilic age, with a glance toward the eschatological future. The work represented by 4 Q245-which is of uncertain relationship to the previous two manuscripts-deployed genealogies as the historiographical mechanism of choice. In the available fragments, these trace the historic lines of priests and kings from their inception into the Second Temple period before a concluding section speculating on the eschatological future.

The question is whether the four kingdoms motif is present in these previously unknown Daniel traditions. On the one hand, there is no indication of this in 4Q245. On the other, 4Q243 16 has been interpreted along such lines. Re-evaluation of the text and limited context of this fragment, however, indicates this is unlikely. Since there are several textual problems with this tiny fragment, I present it here with an independent transcription, translation, and selective notes for revised readings. Following this, I will critique past readings of the fragment for a four kingdoms motif and offer a new interpretation of its historiographical structure.

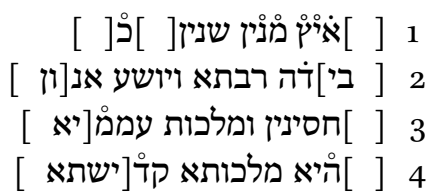

$1 \quad[\ldots] \ldots$ number of years $[\ldots] \ldots[\ldots]$

2 [with] a great $[\mathrm{h}$ ] and and he will deliver th[em ...]

$3[\ldots]$ strong and [the] kingdoms of the people $[\mathrm{s} . .$.

$4[\ldots]$ it is the ho[ly] kingdom $[\ldots]$

Gauging the possibility of a four kingdoms scheme in this fragment comes down to interpreting fleeting content at the fringes of lines 1 and 4 . The issue is what fragmentary word precedes the term "years" in line 1 and how (if at all) this relates to the reference to a "kingdom" in line 4. Before making this determination, however, readings in both lines require revaluation.

The limited content of line 1 is at once fragmentary and suggestive. The initial word of the fragment is known by at least three partial characters. Collins and Flint adopt Milik's transcription איץ at the beginning of the line. 
They tentatively render "oppressed(?)" based on the noun subsequent Aramaic. ${ }^{31}$ However, the verb with this meaning is unknown in literature of the period.

The second word of the fragment is also extant only in part. Both old (PAM 43.247) and new (Plate 908, B-366933) images reveal the horizontal baseline strokes of two characters preceding a clear yod-final nun ending of the word in question. These strokes have been transcribed with uncertainty, for

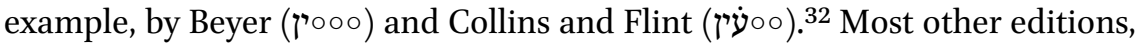
however, venture variations on the reading שבעין ("seventy").33 The challenge here, however, is that the physical space is not enough to accommodate the shin, bet, ayin required for the reading. Aware of this, Collins and Flint posit that the bet "may have been supralinear." 34 If the ink trace preceding the two final extant characters is an ayin, which is not certain (see below), the number ארבעין ("forty") is at first glance possible. ${ }^{35}$ Yet this reading has an even greater challenge of insufficient space. In translation, Cook provided both possibilities: "seve]nty (or [for]ty) years." 36

My rendering included above is a new proposal for a word yet to be considered. Working through the options for eligible reconstructions of contemporary Aramaic words that both fit the physical and literary context, the word ("number") deserves consideration. ${ }^{37}$ Admittedly, the biggest challenge with

31 J. T. Milik, "Prière de Nabonide et autres écrits d'un cycle de Daniel," RB 63 (1956): 407-15; John J. Collins and Peter W. Flint, "Pseudo-Daniel," in Qumran Cave 4.XVII: Parabiblical Texts, Part 3, ed. George Brooke, et al., DJD 22 (Oxford: Clarendon Press, 1996), 108. See also Klaus Beyer, Die aramäischen Texte vom Toten Meer: Band 2 (Göttingen:Vandenhoeck \& Ruprecht, 2004), 140. For the noun, see Marcus Jastrow, Dictionary of the Targumim, the Talmud Babli and Yerushalmi, and the Midrashic Literature (Peabody: Hendrickson, 2006), 59 .

32 Beyer, Die aramäischen Texte vom Toten Meer: Band 2, 140; Collins and Flint, "PseudoDaniel," 108.

33 Compare the following: שבבْ]ע[ (Milik, "Prière de Nabonide," 413), שב]ע[ין (Joseph A. Fitzmyer and Daniel J. Harrington, A Manual of Palestinian Aramaic Texts (Second Century B.C.-Second Century A.D.) [Rome: Pontificio Istituto Biblico, 2002], 6), שבע] (García Martínez, Qumran and Apocalyptic: Studies on the Aramaic Texts from Qumran, STDJ 9 [Leiden: Brill, 1992], 139), and ששין] (Florentino García Martínez and Eibert Tigchelaar, Dead Sea Scrolls: Study Edition, [Leiden: Brill, 1997], 49o). Collins and Flint ("Pseudo-Daniel," 109) include the translation "[seven]ty(?)" in their rendering.

34 Collins and Flint, "Pseudo-Daniel," 108.

35 Robert Eisenman and Michael Wise, The Dead Sea Scrolls Uncovered (New York: Penguin Books, 1993), 66.

36 Wise, Abegg, and Cook, The Dead Sea Scrolls: A New Translation, 344.

37 For a list of potential words for reconstruction, see Ruth Sander and Kerstin Mayerhofer, Retrograde Hebrew and Aramaic Dictionary, JAJSup 1 (Göttingen: Vandenhoeck \& Ruprecht, 2010), 189-91. 
this new proposal is the distance between the lower leg of the possible nun and extant yod. In this hand, yods routinely edge up to, or intersect with, the vertical strokes of the following character (e.g., 4Q243 8 3; 13 3; 16 1; 21 1). However, an analogous critique could be made of the reading of the penultimate character as an ayin, as these rarely if ever extend so south of the line the manuscript (e.g., 4Q243 16 3; 24 4). Likewise, if the character is a bet, as required by Collins and Flint's proposed reconstruction, we must contend with an oddly shaped and placed letter. For this letter too, the scribe uniformly extends the lower leg of the bet to intersect with the following character (e.g., 4Q243 $62 ; 123$, $4 ; 162$ ). In this way, none of the current proposals for this fragmentary form are without palaeographical problems and/or require suggested hypothetical emendations.

The final word of line 4 is known only by the heads of a qof and possible daleth. Milik reconstructed the form קד] ("first") here, which is adopted in most subsequent editions. ${ }^{38}$ The reading "holy," accepted here, is made in light of Collins and Flint's reconstruction ישתאה, which is equally uncertain but introduces less interpretive difficulty to the fragment. ${ }^{39}$ With the readings in lines 1 and 4 now problematized, we can now explore the scope and limits of the fragment's historiographical structure.

As indicated in the textual notes above, most past editions read and reconstruct "seventy" in line 1 . At best, this reading is remotely possible but certainly speculative. Therefore, it cannot serve as a guide for interpretation. Nonetheless, the history of research built upon it. Beginning with Milik's preliminary edition in 1956, this fragment was presented under the title "Premier de quatre royaumes," indicating the text spoke of the emergence, rule, or duration of the initial kingdom in a four kingdom scheme. This is in part due to the heavily reconstructed reading of yet another fragmentary term in line 4 .

Reconstructions of the final word of the fragment generally fall into two camps: the text refers to either the "first" kingdom or a "holy" kingdom. García Martínez suggested that "[t]he number [seventy] is taken, no doubt, from Jer 25:11-12 and 29:10," which forms the basis of the seventy weeks interpretation of Dan 9:2. ${ }^{40}$ Building on Milik's suggestion, García Martínez understood the fragment as plugging into the origins of a four kingdoms chronology. $\mathrm{He}$ concluded, "[s]ince in Daniel this first kingdom lasted until the return from

38 Milik, "Prière de Nabonide," 413. See also Fitzmyer and Harrington, A Manual of Palestinian Aramaic Texts, 6; García Martínez, Qumran and Apocalyptic, 139; Beyer, Die aramäischen Texte vom Toten Meer: Ergänzungsband, 106; Beyer, Die aramäischen Texte vom Toten Meer: Band 2, 140; and Eisenman and Wise, The Dead Sea Scrolls Uncovered, 66.

39 Collins and Flint, "Pseudo-Daniel," 108.

40 García Martínez, Qumran and Apocalyptic, 143. 
exile and our text depends on Daniel, the duration of this first kingdom must be the same as in the biblical book."41 On the more likely reading "holy," Collins and Flint noted that the full phrase cannot be a "kingdom of holy ones," as known from Daniel, since this would require a construct or particle די די , which are not present. ${ }^{42}$

Any interpretation of this fragment must contend with four issues. First, the reading "seventy" is far from clear and, therefore, is not a signpost for the duration of an empire's rule or the exile. Second, even if the reading "seventy" is accepted and taken as a reference to the post-exilic period, it is difficult to account for the intermittent deliverance implied in lines 2-3 before the arrival of the alleged first kingdom of line $4 .^{43}$ Third, while the Pseudo-Daniel materials are thoroughly historiographical, as Collins and Flint noted, "nothing else in pseudo-Daniel suggests a four-kingdom pattern." ${ }^{44}$ Fourth, the assumption that Pseudo-Daniel presupposes or is a secondary development out of "biblical" Daniel is, yet again, unfounded.

In view of these challenges, I offer an alternative interpretation based on a new proposed tentative reading מִנין שנין ("number of years") in line 1. The Aramaic word מנין is known from Ezra 6:7.45 The Hebrew Scriptures include five other variations on the phrase "number of years" (i.e., paired configura-

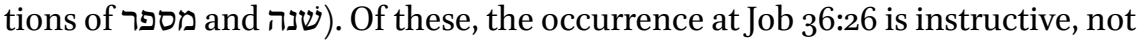
least because the translator of ${ }_{11 Q 10} 284$ rendered the Hebrew מספר שניו as ומנין שנוהי in Aramaic (both, "the number of his years"). Here in Job, the idiom describes the unsearchable and innumerable ages of God. A second occurrence is found in Dan 9:2, which reads מספר השנים. Variations on this phrase occur also in other ancient Jewish literature, generally in reflections or projections of long life and aging (Jub. 23.27; Wis 4:8). The Damascus Document features the analogous Hebrew phrase in a comment on the building tension of the present age and end of days. "When the number of years (למספר השנים) of this present age are complete, there will be no further need to be connected to the

41 García Martínez, Qumran and Apocalyptic, 144.

42 Collins and Flint, "Pseudo-Daniel," 151.

43 Collins and Flint, "Pseudo-Daniel," 15o. As Collins observed, the figure is also found in 4Q390 1 2; 2 i 6 with reference to other periods (John J. Collins, "Pseudo-Daniel," in Outside the Bible: Ancient Jewish Writings Related to Scripture, eds. Louis H. Feldman, James L. Kugel, and Lawrence H. Schiffman [Philadelphia: Jewish Publication Society of America, 2013], 619).

44 Collins and Flint, "Pseudo-Daniel," 150.

45 The Aramaic מנין also occurs a dozen times in Egyptian documentary texts, perhaps not surprisingly to specify amounts of currency or commodities. See Dirk Schwiderski, Die alt- und reichsaramäischen Inschriften, Band 1: Konkordanz, FSBP 4 (Berlin: Walter de Gruyter, 2008), 532. 
house of Judah, but instead each will stand on his own tower" (CD 4:10-12).46 Finally, $1 \mathrm{QH}^{\mathrm{a}}$ 9:26 references תקופות מספר שני עולם (the numbered seasons of eternal years") in a statement on how all ages and cycles are set and inscribed before God.

In light of the preceding uses of the phrase "number of years," the proposed occurrence at 4Q243 161 would be a natural way of referring simply to a duration of time, perhaps even in the context of an eschatological outlook for an era of indescribable length. Such a forecast of longevity fits with the reference to a "holy kingdom" in line 4. From this perspective, then, the form in line 1 is not a cardinal number specifying an exact duration of time within a four kingdoms context. Rather, it is an idiom for a generic figure of longevity. It is neither related to ex eventu speculation of the duration of exile nor the arrival of an ancient near eastern kingdom. From this perspective, the fragment perhaps referred to the arrival and sustainability of divine rule in the eschatological age.

While this example involved dismantling a four kingdoms interpretation of 4 Q243 16, the net result was a potentially new perspective on the broader apocalyptic historiography developed in an early Aramaic Daniel tradition.

\section{Conclusion: An Aramaic Avenue for the Four Kingdoms Scheme in Ancient Judaism}

This tour through a cross-section of Aramaic writings discovered in the Judaean Desert caves provided both new texts and fresh contexts in which to study the formation and application of four kingdoms chronologies in writings of the mid-Second Temple period. This mechanism was neither static for a fixed group of empires nor isolated to a single historiographical work. It was shown to be formative and generative to growing traditions (i.e., Daniel), had a broader currency in previously unknown texts (i.e., 4 QFour Kingdoms), sat alongside other views of eschatological imperial succession or ex eventu prophecy of geopolitical movements (i.e. New Jerusalem and Tobit), and, at times, evaporated upon closer inspection (i.e., Pseudo-Daniel). In addition to these observations on the foregoing individual texts, I will conclude with some remarks on the situation and development of this mechanism in the context of the larger Qumran Aramaic corpus.

46 Translation from Wise, Abegg, and Cook, The Dead Sea Scrolls: A New Translation, 55, with slight revision to bring the idiom in question to the fore. 
First, the texts above both draw upon and contribute to a broad array of conceptions for time, history, and expectation in the Aramaic Dead Sea Scrolls. By a blend of accident and intention, the four kingdoms motif has become one of the more visible and studied expressions of apocalyptic historiography in ancient Jewish Aramaic scribal culture. In many ways, this is an observation made in retrospect due to the canonization of Daniel. Like the writers of the book of Daniel, however, those behind the Aramaic texts also deployed many and manifold historiographical mechanisms to consider the past, account for the present, and clock the eschatological future (e.g., Urzeit und Endzeit typologies, periodizations with reference to "weeks" or "jubilees," reflections on exile along an eschatological axis, and strategically structured genealogies). The recovery of these lost texts, then, revealed that our four kingdoms motif was appropriated broadly in the thought and literature of the mid-Second Temple period yet it also functioned in concert with other strategies used in the processes of apocalyptic historiography. 47

Second, this raises the question of whether or not the four kingdoms motif should be considered a "Danielic" theme in the context of the Dead Sea Scrolls. The answer is both yes and no. While there is a need for continued study of individual and clusters of Aramaic texts in this corpus, at present, it seems the only place this theme is demonstrably Danielic is in the formation of the Hebrew chapters of Daniel 8-12. As noted above, the composition of these chapters were occasioned by an updating and extension of the chronologies from the preceding Aramaic chapters. Of course, the redaction and reception of both sections of the hybrid work is far more complex than I have stated here. Nonetheless, the latter and later half of Daniel received the chronological framework of the earlier Aramaic sections and developed them within that stream of the Danielic tradition.

However, beyond the reformulation and particularization of the four kingdoms concept in Hebrew Daniel 8-12, we do not have certain evidence to suggest the scribes of the Aramaic texts understood our theme as strictly "Danielic." At first glance, the so-called Pseudo-Daniel materials seemed to contribute a new Danielic take on the four kingdoms motif, but this was an over-reading of the fragments: we found Daniel but no four kingdoms chronology. The opposite was the case for the Aramaic 4 QFour Kingdoms text: there we confirmed the chronology but cannot confirm the identity of the seer. If New Jerusalem is included in the mix, then we would have an important example of the

47 On the other varieties of time structures in the Aramaic texts, particularly the Enochic traditions, see the contribution by Loren Stuckenbruck in this volume. 
development of a potential four kingdoms motif, or at least the understanding of waxing and waning empires in the apocalyptic historiography that was not formed on the basis of Danielic tradition. In that case, the work is developed in conversation with another line of tradition, Ezekiel 40-48. Perhaps more than anything, the lesson learned here is the need for nuance in our descriptors of texts and themes. Judaism, Christianity, and Western Culture may have received the four kingdoms theme predominantly through a Danielic tradition, but this should not be the only lens through which we study and explain texts from the pre-canonical era.

Third, the discovery of a larger literary heritage of ancient Jewish Aramaic writings from the mid-Second Temple period provides a new space to consider the formation of traditions as well as the exchange of ideas across cultures. Ongoing research on these materials has shown that Aramaic scribal culture was immersed in their own national and ancestral traditions as well as in dialogue with the intellectual and literary cultures of people groups to the east and west. This is true on a range of topics, from science and mathematics, to medicine and divination, to lore and genres. Three, four, and even five kingdoms motifs were developed in a variety of writings from classical and ancient Near Eastern sources. In view of the documented exchange and interaction with international cultural traditions in some of the Aramaic texts, I would add that the style of historiography that involves enumerating kingdoms in succession first entered ancient Jewish tradition across the bridge provided by the scribal culture of the Aramaic texts. To say these scribes simply "borrowed" or were "influenced" by their neighbors on this item or the foregoing list misses the point. Rather, they were part of this social and intellectual culture, not apart from it. The partial view of this Aramaic scribal culture granted by the Qumran fragments provides the opportunity to study how scribes created, cultivated, and contributed to emerging traditions in and beyond canonical literatures.

\section{Bibliography}

Baillet, M., J. T. Milik, and R. de Vaux. Les 'petites grottes' de Qumran. DJD 3. 2 vols. Oxford: Clarendon, 1962.

Beyer, Klaus. Die aramäischen Texte vom Toten Meer samt den Inschriften aus Palästina, dem Testament Levis aus der Kairoer Genisa, der Fastenrolle und den alten talmudischen Zitaten: Ergänzungsband. Göttingen: Vandenhoeck \& Ruprecht, 1994.

Beyer, Klaus. Die aramäischen Texte vom Toten Meer samt den Inschriften aus Palästina, dem Testament Levis aus der Kairoer Genisa, der Fastenrolle und den alten talmudischen Zitaten: Band 2. Göttingen: Vandenhoeck \& Ruprecht, 2004. 
Brooke, George. "Parabiblical Prophetic Narratives." Pages 271-301 in vol. 1 of The Dead Sea Scrolls After Fifty Years: A Comprehensive Assessment. Edited by Peter W. Flint and James C. VanderKam with the assistance of Andrea E. Alvarez. Leiden: Brill, 1998.

Burkert, Walter. "Apokalyptik im frühen Griechentum:Impulse und Transformationen.” Pages 235-54 in Apocalypticism in the Mediterranean World and the Near East. Edited by David Hellholm. Tübingen: Mohr Siebeck, 1983.

Collins, John J. A Commentary on the Book of Daniel. Hermeneia. Minneapolis: Fortress, 1993.

Collins, John J. "Apocalypticism and Literary Genre in the Dead Sea Scrolls." Pages 403-30 in vol. 2 of The Dead Sea Scrolls After Fifty Years: A Comprehensive Assessment. Edited by Peter W. Flint and James C. VanderKam with the assistance of Andrea E. Alvarez. Leiden: Brill, 1998-1999.

Collins, John J. "Pseudo-Daniel." Pages 614-19 in vol. 1 of Outside the Bible: Ancient Jewish Writings Related to Scripture. Edited by Louis H. Feldman, James L. Kugel, and Lawrence H. Schiffman. Philadelphia: Jewish Publications Society, 2013.

Collins, John J. and Peter W. Flint, "Pseudo-Daniel." Pages 95-164 in Qumran Cave 4.XVII: Parabiblical Texts, Part 3. Edited by George Brooke, John Collins, Torleif Elgvin, Peter Flint, Jonas Greenfield, Erik Larson, Carole Newsom, Émile Puech, Lawrence H. Schiffman, Michael Stone, and Julio Trebolle Barrera in consultation with James VanderKam. DJD 22. Oxford: Clarendon Press, 1996.

Cross, Frank Moore. The Ancient Library of Qumran. 3rd ed. Minneapolis: Fortress Press, 1995.

DiTommaso, Lorenzo. The Dead Sea New Jerusalem Text: Contents and Contexts. TSAJ 11. Tübingen: Mohr Siebeck, 2005.

Ernest, Lucas. "The Origin of Daniel's Four Empires Scheme Re-Examined." TynBul 40 (1989): 185-202.

Eisenman, Robert and Michael Wise. The Dead Sea Scrolls Uncovered. New York: Penguin Books, 1993.

Fishbane, Michael. Biblical Interpretation in Ancient Israel. Oxford: Clarendon Press, 1988.

Fitzmyer, Joseph A. "The Hebrew and Aramaic Fragments of Tobit from Qumran Cave 4." свQ (1995): 655-75.

Fitzmyer, Joseph A. Tobit. CEJL. Berlin: Walter de Gruyter, 2003.

Fitzmyer, Joseph A. and Daniel J. Harrington. A Manual of Palestinian Aramaic Texts (Second Century B.C.-Second Century A.D.). Rome: Pontificio Istituto Biblico, 2002.

Flint, Peter W. “The Daniel Tradition at Qumran." Pages 329-67 in vol. 2 of The Book of Daniel: Composition and Reception. Edited by John J. Collins and Peter W. Flint with the assistance of Cameron VanEpps. VTSup 83. FIOTL 2. Leiden: Brill, 2001.

Flusser, David. "The Four Empires in the Fourth Sibyl and in the Book of Daniel." IOS 2 (1972): 148-75. 
García Martínez, Florentino. Qumran and Apocalyptic: Studies on the Aramaic Texts from Qumran. STDJ 9. Leiden: Brill, 1992.

Gruenthaner, Michael J. "The Four Empires of Daniel I: The Scriptural Evidence." свQ 8.1 (1946): $72-82$.

Gruenthaner, Michael J. "The Four Empires of Daniel II: The Evaluation of the Scriptural Evidence." свQ 8.2 (1946): 201-12.

Hasel, Gerhard F. "The Four World Empires of Daniel 2 against Its Near Eastern Environment." JSOT 4 (1979): 17-30.

Hogeterp, Albert L. A. "Daniel and the Qumran Daniel Cycle: Observations on 4QFour Kingdoms $^{\text {a-b }}$ (4Q552-553)." Pages $173^{-91}$ in Authoritative Scriptures in Ancient Judaism. Edited by Mladen Popović. JsJs 141. Leiden: Brill, 2010.

Jastrow, Marcus. Dictionary of the Targumim, the Talmud Babli and Yerushalmi, and the Midrashic Literature. Peabody: Hendrickson, 2006.

Kooij, Arie van der. "Compositions and Editions in Early Judaism: The Case of Daniel." Pages 428-48 in The Text of the Hebrew Bible and Its Editions: Studies in Celebration of the Fifth Centennial of the Complutensian Polyglot. Edited by Andrés Piquer Otero and Pablo A. Torijano Morales. THBSup 1. Leiden: Brill, 2016.

Kratz, Reinhard G. Translatio imperii: Untersuchungen zu den aramäischen Danielerzählungen und ihrem theologiegeschichtlichen Umfeld. WMANT 63. NeukirchenVluyn: Neukirchener Verlag, 1987.

Kratz, Reinhard G. "The Visions of Daniel." Pages 91-113 in vol. 1 of The Book of Daniel: Composition and Reception. Edited by John J. Collins and Peter W. Flint with the assistance of Cameron VanEpps. VTSup 83. FIOTL 2. Leiden: Brill, 2001.

Milik, J. T. "Prière de Nabonide et autres écrits d'un cycle de Daniel." $R$ в 63 (1956): 407-15. Neujahr, Matthew. Predicting the Past in the Ancient Near East: Mantic Historiography in Ancient Mesopotamia, Judah, and the Mediterranean World. BJS 354. Providence: Brown University Press, 2012.

Newsom, Carol A. with Brennan W. Breed. Daniel: A Commentary. отL. Louisville: Westminster John Knox, 2014.

Perrin, Andrew B. "Redrafting the Architecture of Daniel Traditions in the Hebrew Scriptures and Qumran." JTs (forthcoming).

Perrin, Andrew B. The Dynamics of Dream-Vision Revelation in the Aramaic Dead Sea Scrolls. JAJSup 19. Göttingen: Vandenhoeck \& Ruprecht, 2015.

Portier-Young, Anathea E. Apocalypse Against Empire: Theologies of Resistance in Early Judaism. Grand Rapids: Eerdmans, 2011.

Puech, Émile. Qumrân Grotte 4.XXVII:Textes araméens, deuxième partie: $4 Q_{550-4}$ Q575a, 4Q580-4Q587. DJD 37. Oxford: Clarendon, 2009.

Reynolds III, Bennie H. Between Symbolism and Realism: The Use of Symbolic and NonSymbolic Language in Ancient Jewish Apocalypses 333-63 B.C.E. JAJSup 8. Göttingen: Vandenhoeck \& Ruprecht, 2011. 
Sander, Ruth and Kerstin Mayerhofer. Retrograde Hebrew and Aramaic Dictionary. JAJSup 1. Göttingen: Vandenhoeck \& Ruprecht, 2010.

Schwiderski, Dirk. Die alt- und reichsaramäischen Inschriften, Band 1: Konkordanz. FSBP 4. Berlin: Walter de Gruyter, 2008.

Segal, Michael. "Calculating the End: Inner-Danielic Chronological Developments." VT 68 (2018): 272-96.

Sharon, Nadav. "Four Kingdoms' in the Dead Sea Scrolls? A Reconsideration." DSD 27 (2020): forthcoming.

Stuckenbruck, Loren T. "The Formation and the Re-Formation of Daniel in the Dead Sea Scrolls." Pages 101-30 in The Bible and the Dead Sea Scrolls, Volume 1: Scripture and the Scrolls. Edited by James H. Charlesworth. Waco: Baylor University Press, 2006.

Swain, Joseph Ward. "The Theory of the Four Monarchies: Opposition History under the Roman Empire." CP 35 (1940): 1-21.

Tigchelaar, Eibert. "Aramaic Texts from Qumran and the Authoritativeness of Hebrew Scriptures: Preliminary Observations." Pages $155^{-71}$ in Authoritative Scriptures in Ancient Judaism. Edited by Mladen Popović. JsJs 141. Leiden: Brill, 2010.

Ulrich, Eugene C. The Dead Sea Scrolls and the Origins of the Bible. SDSSRL. Grand Rapids: Eerdmans, 1999.

Vermes, Géza. Scripture and Tradition in Judaism: Haggadic Studies. SPB 4. Leiden: Brill, 1961.

Weeks, Stuart, Simon Gathercole, and Loren Stuckenbruck. The Book of Tobit: Texts from the Principal Ancient and Medieval Traditions. FoSub 3. Berlin: Walter de Gruyter, 2004.

Wise, Michael, Martin Abegg Jr., and Edward Cook. The Dead Sea Scrolls: A New Translation. New York: Harper One, 2005.

Zsengellér, József, ed. Rewritten Bible after Fifty Years: Texts, Terms, or Techniques. Jsjs 166. Leiden: Brill, 2014. 